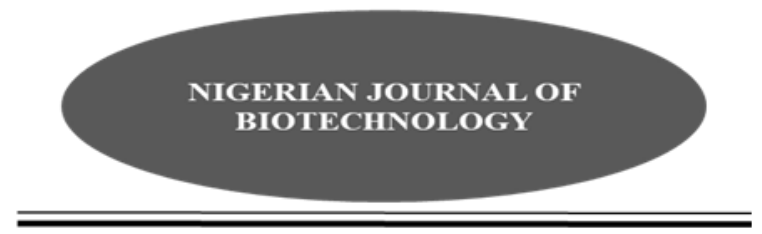

\title{
Assessment of Physicochemical and Fatty Acids Composition of Crude Seed Oil Extract of Azadirachta indica Adr. Juss. for its potential in Biodiesel Production
}

\author{
${ }^{* 1}$ Chomini, M.S., ${ }^{1}$ Joshua V.I., ${ }^{1}$ John, A.R. ${ }^{2}$ Ishaya, M.P. \\ ${ }^{1}$ Forestry Technology Department, Federal College of Forestry, Jos, P.M.B. 2019, Plateau State, Nigeria. \\ ${ }^{2}$ Pest Management Technology Department, Federal College of Forestry, Jos, P.M.B. 2019, Plateau State, \\ Nigeria.
}

\begin{abstract}
This study investigates the physico-chemical and fatty acids composition of crude seed oil extracts of Azadirachta indica. The main objective was to evaluate some biodiesel characteristics of the crude seed oil extract of Azadirachta indica. The procedures of the Association of Official and Analytical Chemist (AOAC) were used for assessment of some physical, biochemical, and fatty acids constituents of the test seed oil extract. The physical properties assayed for indicate that the oil is liquid at room temperature, non-drying, with specific gravity, with flash and melting points of $0.910 \pm 0.08 \mathrm{~g} / \mathrm{cm}^{3}, 80 \pm 2.10^{\circ} \mathrm{C}$ and $76 \pm 1.60^{\circ} \mathrm{C}$ respectively. The chemical properties included $66.77 \pm 2.55 \mathrm{~g} / 100 \mathrm{~g}$ (iodine value), $1.465 \pm 0.07$ (refractive index@30 3 C), 212.96 $\pm 1.16 \mathrm{mgKOH} / \mathrm{g}$ (saponification value), $0.39 \pm 0.16 \mathrm{meq} / \mathrm{Kg}$ (peroxide value), $4.24 \pm 0.12 \mathrm{mgKOH} / \mathrm{g}$ (acid value), $2.20 \pm 0.12 \mathrm{~mm}^{2} / \mathrm{s}$ (viscosity value), $56.91 \pm 2.19$ (cetane number), $39.21 \pm 1.11 \mathrm{MJ} / \mathrm{kg}$ (calorific value) and $2.13 \pm 0.05 \% \mathrm{w} / \mathrm{w}$ (free fatty acids). Fatty acids composition of the crude seed oil of $A$. indica obtained were linoleic, hexadecanoic, octadecanoic and alpha linolenic acids, with retention time and \% composition of $18.2 \mathrm{~min}$ and 10.8 $\pm 0.50 \%, 22.2 \mathrm{~min}$ and $30.01 \pm 1.79 \%, 18.2 \mathrm{~min}$ and $59.10 \pm 2.22 \%$, and $20.2 \mathrm{~min}$ and $0.09 \pm 0.02 \%$ respectively. The crude seed oil extract clearly presents a potential as a biodiesel substrate for incorporation as a proximate blend in auto-engines. This therefore would necessitate intensive afforestation efforts of the plant species for sustainable utilization.
\end{abstract}

Keywords: Azadirachta indica, Biodiesel, physico-chemical, fatty acids, crude seed oil, extracts

\section{Introduction}

The continuous increase in energy demand remains a global phenomenon. This increase has been largely traced to rise in human population and industrialization, which have continually placed pressure on basic economic infrastructure (Khan et al., 2014; Demirbas et al., 2015a). Fossil fuels which currently dominate the global energy landscape are faced with numerous threats ranging from price stability, issue of sustainability, dependence and energy security (Banik et al., 2018), environmental impacts and C- emissions as well as ecosystem stability (Sylvester et al., 2013). Biodiesel is a methyl or ethyl ester obtained through 
esterification of edible and non edible oils and fats of organic origins (Wilson, 2010). The imperativeness for consideration of biodiesel options against the fossil diesel commonly in use stemmed from its number of reported advantages ranging from reduced exhaust emissions, improved biodegradability, reduced toxicity, improved lubricity, higher flash point, and lower vapour pressure (Knothe and Steidley, 2005; Adewuyi et al., 2014; Syndia et al., 2015). Moreso, the fossilized diesels have recorded high oil prices coupled with high greenhouse gas emissions making its continuous use unattractive and consequently turning attention to investment in biofuels (Adewuyi et al., 2014).

The use of cheap, non-edible seed oils, animal fats, and waste oils as raw feedstock for manufacturing of non-fossil diesel provides a cost- saving process. So, the search for nonedible underutilized seed oils as feedstock for producing biodiesel is important (Adewuyi et al., 2014). Most of the feedstock currently incorporated in biodiesel were plant - based (Demirbas, 2015b). They include mustard seed, peanut, sunflower, and cotton seed. Soybean oil is commonly used in the United States, and rapeseed oil (Europe), coconut oil and palm oils (in Malaysia and Indonesia) for biodiesel production (Demirbas et al., 2016).

There has been a dramatic increase in prices of these vegetable oils, due to their rising demands as feedstock, competing for foods (Atabani et al., 2012). This definitely affects the economic viability of these substrates for the biodiesel industry (Keneni and Marchetti, 2017). This definitely rendered them not feasible and unsustainable, thereby engendering the consideration less expensive and less competitive and inedible oil-rich plant biomass (Avhad and Marchetti, 2015).

Several non-edible plant seed oils are being investigated to assess their suitability based on physico-chemical, fatty acids and other biodiesel properties. These include oils from Jatropha (Umaru and Aberuagba, 2012), Sclerocarya birrea (Ejilah et al., 2012), Hevea brasiliensis (Krishnakumar et al., 2013), Balanites aegyptiaca (Ogala et al., 2018), Hura crepitans (Sidohounde et al., 2019). The Neem tree (Azadirachta indica $A$. Juss), an evergreen member of the Meliaceae (Mahogany) family and native of India, grows in the tropical and sub tropical Africa (Abubakar, 2016). The species has been reported to have significant medicinal uses, as anti-dermatophytes, malaria, asthma, and intestinal worms (Nde et al., 2015), as well as other useful industrial utilizations (Syndia et al., 2015). Some efforts have been made to incorporate the seed oil extracts of this plant in biodiesels (Banu et al., 2018; Madai et al., 2020). The present study, therefore assesses the physico-chemical and fatty acid compositions of crude seed oil extracts of Azadirachta indica as potential biodiesel and industrial substrate.

\section{Materials and Methods}

\section{Collection and Preparation of Kernels of Azadirachta indica}

The seeds of neem (Azadirachta indica) called dogonyaro in Hausa (Adewoye and Ogunleye, 2012), sourced from Toro - Bauchi State of Nigeria, packed and transported in sterilized polythene bags and thereafter identified at the herbarium of the Federal College of Forestry, Jos (FCFJ), Plateau State, (with a voucher number of FHJ31720). They were cleaned and then depulped by soaking in water for $24 \mathrm{hrs}$. The depulped seeds were dried at room temperature $\left(26.1^{\circ} \mathrm{C}\right)$ for 10 days and peeled to separate the shell from the kernel.

\section{Extraction of Crude Seed Oil of Azadirachta indica}

The extraction of the crude seed kernel oil of $A$. indica was carried out, using modified methods of Syndia et al., (2015) and Hamadou et al., (2020). The kernels $(1.0 \mathrm{~kg})$ were mechanically decorticated (dehulling) to obtain the almonds, which were spread in a tray and air - dried for 10 days in the chemistry lab, FCFJ. The dried almonds were weighed, pulverized with mortar and pestle, at temperatures between 45$47^{\circ} \mathrm{C}$ to dryness and liquefied to ease extraction. (Tesfaye et al., 2018; Banik et al., 2018). The oil was extracted by traditional methods by pouring the toasted kernels into hot water in a mortar and allowed to float, followed by stirring, using a pestle then decantation and drying (Abu-Al-Futuh,1989; Hamadou et al., 2020) (Figure 1). The extracted seed oil was 
assayed for some physical, biochemical, diesel and fatty acids constituents

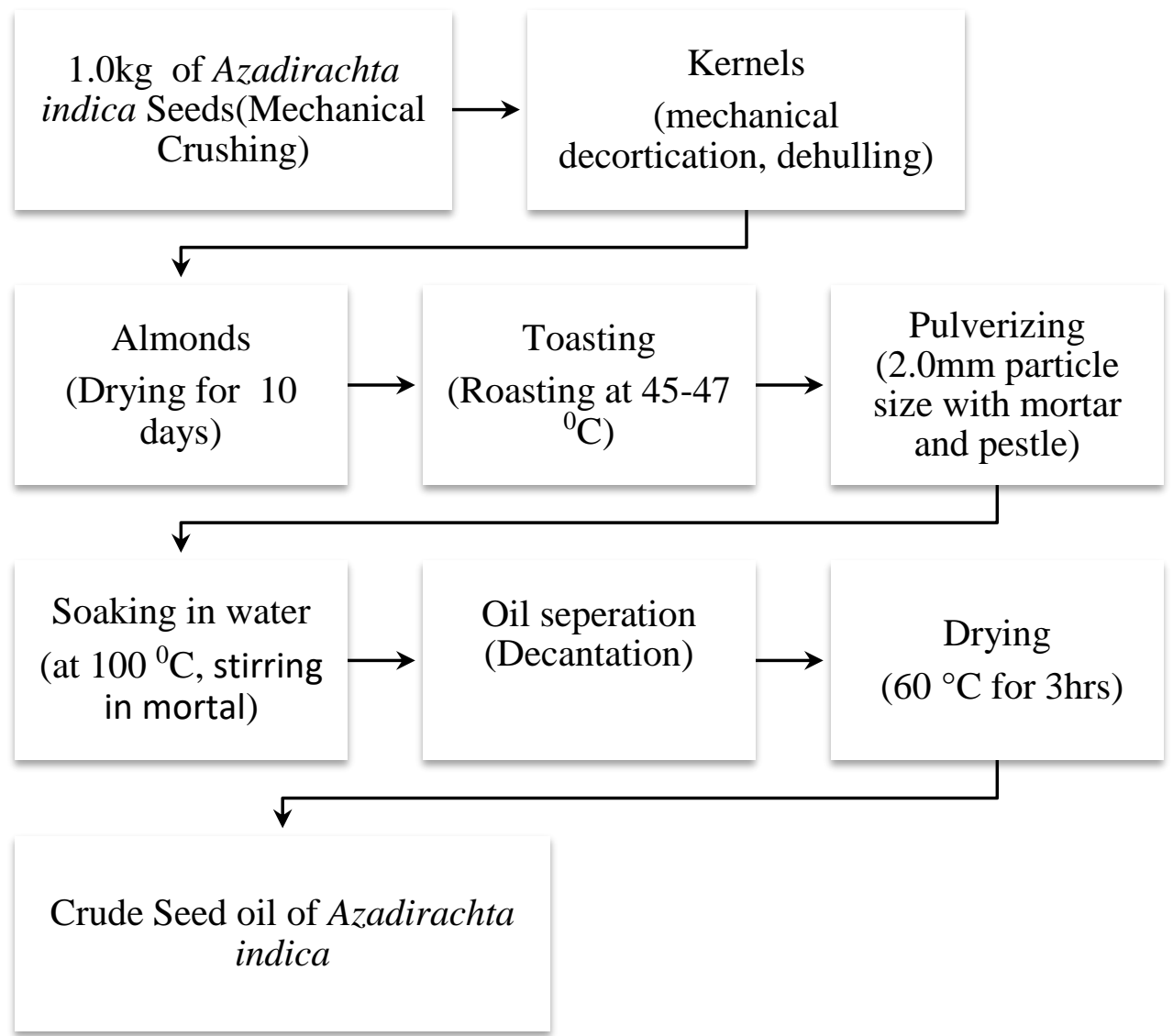

Figure 1: Flow chart of Extraction Process of Crude Seed oil of Azadirachta indica

Determination of Physical and biochemical Composition of Crude Seed oil extract of Azadirachta indica

The crude seed oil extract of $A$. indica was subjected to standard methods of the American Society of Testing Materials (ASTM 2003 ASTM D6751-08) as described by Umaru and Aberuagba, (2012), to determine the physical and biochemical properties. The acid value was assessed using titration method, involving dissolution of $2.0 \mathrm{~g}$ of the oil samples in $50 \mathrm{~cm}^{3}$ of mixed solvent $\left(25 \mathrm{~cm}^{3}\right.$ dimethyl ether with 25 $\mathrm{cm}^{3}$ of ethanol precisely made up to $\mathrm{pH} 7.0$, by addition of $0.1 \mathrm{M} \mathrm{NaOH}$, and $1 \%$ phenolphthalein solution as an indicator). Relative density was determined as described by Jibril et al. (2012), viscosity, using Clandon viscometer, model: VT03 viscometer (Umaru and Aberuagba, 2012). The saponification value, peroxide, iodine value, specific gravity were determined according to the methods of Umaru and Aberuagba (2012).

\section{Determination of Fatty Acids Composition of Azadirachta indica}

The fatty acids composition of the crude seed oil of Azadirachta indica was determined by modified methods of Rizvi (2009), using Gas chromatograp hy and Mass Spectrometry (GCMS) of models: QP2010 and HP5973 respectively at the National Research Institute for Chemical Technology (NARICT), Zaria - Kaduna State.

\section{Determination of Some Other Measurable} Quantities of Azadirachta indica crude oil extract

Some important biodiesel properties such as refractive index (R1), cetane number $(\mathrm{CN})$, calorific value (CV) and were determined using reference formulae as follow:- 
The refractive index (R1) was determined using the Perkins formula (1) reported by Babatunde and Bello (2016).

$$
R I=1.45765+0.0001164 I V
$$

Where RI = Refractive Index; IV = iodine value

The cetane number $(\mathrm{CN})$ of the oil extract was evaluated using the formula of Krisnangkura (1986) reported by Adewuyi et al. (2014) in equation (2) below:-

V)

$$
C N=46.3+\frac{5458}{S V}-(0.225 \times
$$

Where SV = Saponification value; IV = iodine value

The calorific value (CV) was computed using the equation of Batel et al. (1980), reported by Adewuyi et al. (2014) in the relationship (3) below:-

$$
C V=-4.187 \mathrm{IV}-38.31 \mathrm{SV}\left(\mathrm{in} \frac{\mathrm{Kj}}{\mathrm{kg}}\right)
$$

Saponification value;

Where IV = iodine value; $\mathrm{SV}=$

\section{Results}

The results of some of the physical properties of crude seed oil of Azadirachta indica showed that the oil is a brown liquid at ambient temperature. The melting and flash points of the crude seed oil extract of $\mathrm{A}$. indica are $76 \pm 1.60^{\circ} \mathrm{C}$ and
$80 \pm 2.10^{\circ} \mathrm{C}$, respectively. The oil is of a nondrying class, with a specific gravity of $0.910 \pm 0.08$ $\mathrm{g} / \mathrm{cm}^{3}$ at $25^{\circ} \mathrm{C}$. The details of the results are shown on Table 1.

The average chemical constituents of the crude seed oil extract of $A$. indica revealed that it has saponification, peroxide, and acid values of $212.96 \pm 1.16 \mathrm{mgKOH} / \mathrm{g}, 0.39 \pm 0.16 \mathrm{meq} / \mathrm{Kg}$ and $4.24 \pm 0.12 \mathrm{mgKOH} / \mathrm{g}$, respectively. While $2.20 \pm 0.12 \mathrm{~mm} / \mathrm{s}, 66.77 \pm 2.55 \mathrm{~g} / 100 \mathrm{~g}$, and $2.13 \pm 0.05 \%(\mathrm{w} / \mathrm{w})$ were the viscosity , iodine and free fatty acids values, respectively (Table 2).

\section{Refractive Index, Cetane Number and Calorific Value}

The refractive index, cetane number $(\mathrm{CN})$, and the calorific value (CV) of the crude kernel oil extract of $A$. indica obtained were $1.465 \pm 0.07$ (@ $30^{\circ} \mathrm{C}$ ), $56.91 \pm 2.19$ and $39.21 \pm 1.11 \mathrm{MJ} / \mathrm{kg}$, respectively (Table 2 ).

\section{Fatty Acids Composition of the Crude Seed Oil Extract of Azadirachta indica}

The fatty acids composition of the crude seed oil extract of Azadirachta indica showed the presence of linoleic acid $\left(\mathrm{C}_{18} \mathrm{H}_{32} \mathrm{O}_{2}\right)$, hexadecanoic acid $\left(\mathrm{C}_{16} \mathrm{H}_{32} \mathrm{O}_{2}\right)$, octadecanoic acid $\left(\mathrm{C}_{19} \mathrm{H}_{32} \mathrm{O}_{2}\right)$ and alpha-linonoic acid $\left(\mathrm{C}_{18} \mathrm{H}_{30} \mathrm{O}_{2}\right)$. These have retention time and percentage composition of $18: 2 \mathrm{~min}$ and $10.8 \pm 0.50 \%, 22: 2 \mathrm{~min}$ and $30.01 \pm 1.79 \%, 18: 2 \mathrm{~min}$ and $59.10 \pm 2.22 \%$ and 22:2 min and $0.09 \pm 0.02 \%$, respectively (Table 3).

Table 1: Physical Properties of Crude Seed Oil Extract of Azadirachta indica

\begin{tabular}{llll}
\hline Physical property & $\begin{array}{c}\text { Azadirachta } \\
\text { indica }\end{array}$ & $\begin{array}{c}\text { Jatropha } \\
\text { curcas }^{\mathbf{2}}\end{array}$ & $\begin{array}{l}\text { Hura } \\
\text { crepitans }^{3}\end{array}$ \\
\hline Colour & Brown & Golden & Pale yellow \\
Oil class & Non-drying & & \\
Melting point $\left({ }^{\circ} \mathrm{C}\right)$ & $76 \pm 1.60$ & & $220-330^{* *}$ \\
Flash point $\left({ }^{\circ} \mathrm{C}\right)$ & $80 \pm 2.10$ & 108 & 152 \\
Specific gravity $\left(\mathrm{g} / \mathrm{cm}^{3}\right)$ & $0.910 \pm 0.08$ & 0.913 & 0.913 \\
\hline Present study), ${ }^{2}($ Umaru and Aberuagba, 2012), & ${ }^{3}($ Ottih et al., 2015) & melting point** \\
Mean values \pm standard deviation for $n=3$ & &
\end{tabular}


Table 2: Comparative Average Chemical Composition of Crude Seed Oil Extract of Azadirachta indica

\begin{tabular}{|c|c|c|c|c|}
\hline Parameter & $\begin{array}{c}\text { Azadirachta } \\
\text { indica }^{1}\end{array}$ & $\begin{array}{c}\text { Jatropha } \\
\text { curcas }^{2}\end{array}$ & $\begin{array}{c}\text { Hura } \\
\text { crepitans }^{3} \\
\end{array}$ & Reference $^{4}$ \\
\hline Refractive index(@30² $)$ & $1.465 \pm 0.07$ & 1.47 & 1.36 & \\
\hline $\begin{array}{c}\text { Saponification value (mg } \\
\mathrm{KOH} / \mathrm{g})\end{array}$ & $212.96 \pm 1.16$ & 190 & 220.19 & \\
\hline Peroxide value (meq/Kg) & $0.39 \pm 0.16$ & 2.0 & 20.00 & \\
\hline Acid value $(\mathrm{mgKOH} / \mathrm{g})$ & $4.24 \pm 0.12$ & 36.2 & 7.09 & 0.60 (EN rec) \\
\hline Iodine value $(\mathrm{g} / 100 \mathrm{~g})$ & $66.77 \pm 2.55$ & 105 & 149.64 & $\begin{array}{c}120(\mathrm{~g} / 100 \mathrm{~g}) \\
(\text { EN rec })\end{array}$ \\
\hline Viscosity value $\left(\mathrm{mm}^{2} / \mathrm{s}\right)$ & $2.20 \pm 0.12$ & 40 & 5.91 & $3.5-5.9$ \\
\hline Cetane number & $56.91 \pm 2.19$ & & $45.62 *$ & 51(EN rec) \\
\hline Calorific value(MJ/kg) & $39.21 \pm 1.11$ & 42 & $39.10 *$ & 35.00 (EN rec) \\
\hline Free fatty acids(\%w/w) & $2.13 \pm 0.05$ & 18.1 & 4.61 & $\begin{array}{c}0.5(\mathrm{EN} / \mathrm{ASTM}) \\
* *\end{array}$ \\
\hline
\end{tabular}

${ }^{1}$ (Present study); ${ }^{2}$ (Umaru and Aberuagba, 2012); ${ }^{\mathbf{3}}$ (Ottih et al., 2015); * (Adewuyi et al., 2014); ${ }^{\text {(Sidohounde et }}$ al., 2018); Mean values \pm standard deviation for $n=3 . * *($ Zahan and Kano, 2018)

Table 3: Fatty Acids Composition of Crude Seed Oil Extract of Azadirachta indica

\begin{tabular}{llllc}
\hline $\mathbf{s} / \mathbf{n}$ & $\begin{array}{l}\text { Retention } \\
\text { Time }(\mathbf{m i n})\end{array}$ & Compound & $\begin{array}{l}\text { Molecular } \\
\text { formula }\end{array}$ & \% composition \\
\hline 1 & 18.2 & Linoleic & $\mathrm{C}_{18} \mathrm{H}_{32} \mathrm{O}_{2}$ & $10.80 \pm 0.50$ \\
2 & 22.2 & Hexadecanoic & $\mathrm{C}_{16} \mathrm{H}_{32} \mathrm{O}_{2}$ & $30.01 \pm 1.79$ \\
3 & 18.2 & Octadecanoic & $\mathrm{C}_{19} \mathrm{H}_{32} \mathrm{O}_{2}$ & $59.10 \pm 2.22$ \\
4 & 20.2 & Alpha-linonenic & $\mathrm{C}_{18} \mathrm{H}_{30} \mathrm{O}_{2}$ & $0.09 \pm 0.02$ \\
& & Four compounds & & Total 100 \\
& & & &
\end{tabular}

Mean values \pm standard deviation for $n=3$

\section{Discussion}

Physical Properties of Crude Seed oil Extract of Azadirachta indica

The crude seed oil extract of $A$. indica gave a dark brown colour which is the characteristics as reported by Ungo-kore et al. (2019), who obtained light and dark brown colour for the crude oil extract of $A$. indica, based on Soxhlet and Cold maceration methods of extraction respectively. Umaru and Aberuagba (2012), reported a golden colour for Jatropha curcas Oil, while a pale yellow coloration was obtained from oil extract of Hura crepitans (Ottih et al., 2015). The melting point of $76 \pm 1.60 .^{\circ} \mathrm{C}$ and a flash point of $80 \pm 2.10^{\circ} \mathrm{C}$ were obtained for crude seed oil extract of $A$. indica, while $108^{\circ} \mathrm{C}$ and $152^{\circ} \mathrm{C}$ were reported for Jatropha curcas seed oil (Umaru and Aberuagba, 2012) and Hura crepitans seed oil (Ottih et al., 2015). The value of the specific gravity of $0.910 \pm 0.08 \mathrm{~g} / \mathrm{cm}^{3}$ was closely consistent with the reported value of $0.913 \mathrm{~g} / \mathrm{cm}^{3}$ (Umaru and Aberuagba, 2012; Ottih et al., 2015). According to Ibeto et al. (2012), the specific gravity of a good oil should be close to the accepted range of $0.87-0.90 \mathrm{~g} / \mathrm{cm}^{3}$ for biodiesel 
(Odjobo and Umar., 2019) . They opined that these values must be maintained within a moderate range for optimal auto engine performance, as higher density oil or its mixture impedes the combustion process..

\section{Biodiesel Properties of Crude Seed Oil Extract of Azadirachta indica}

The crude seed oil extract of $A$. indica recorded a refractive index (RI) value of $1.465 \pm 0.07$ at $30^{\circ} \mathrm{C}$, similar to 1.47 of Jatropha curcas Oil (Umaru and Aberuagba, 2012) and higher than 1.36 of Hura crepitans (Ottih et al., 2015). Ungo-kore et al. (2019), indicated similar range of 1.464-1.465 from neem, while Manji et al. (2013), reported a value of 1.478 from crude B. aegyptiaca oil, Abeer et al. (2020), reported RI of 1.485 from Ocimum basilicum seed oil. They opined that RI varies with temperature, wavelength and unsaturation as well as the chain length of fatty acids. This supported documented claims of Kadam et al. (2012).

The acid value (AV) of $2.49 \pm 0.12 \mathrm{mgKOH} / \mathrm{g}$ obtained from the crude seed oil extract of Azadirachta indica was higher than the $0.6(\mathrm{EN})$ standard value reported by Sidohounde et al. (2018). Other researchers have reported AVs of 6.171-6.520 $\mathrm{mgKOH} / \mathrm{g}, 7.09 \mathrm{mgKOH} / \mathrm{g}$ and $36.2 \mathrm{mgKOH} / \mathrm{g}$ from neem (Ungo-kore et al., 2019), Hura crepitans (Ottih et al., 2015) and Jatropha curcas (Umaru and Aberuagba, 2012), respectively. The AVs determine the edibility, shelf life and extent of industrial applications of such oils. Oils with Low AVs ( $<4.0 \mathrm{mg} \mathrm{KOH} / \mathrm{g}$ ) which are considered non-poisonous to human and livestock, maintain constituent integrity for a long time without becoming rancid (Sunmonu et al., 2017; Nwe et al., 2019). According to Umaru and Aberuagba (2012), oils with very low acid values are indications of good biodiesel potential.

A value of $0.39 \pm 0.16 \mathrm{meq} / \mathrm{kg}$ as peroxide value (PV) of the crude seed oil extract of $A$. indica was slightly above the range of $0.07-.0 .28 \mathrm{meq} / \mathrm{kg}$ as reported by Ungo-kore et al. (2019). Umaru and Aberuagba, (2012) and Ottih et al., (2015) indicated $2.0 \mathrm{meq} / \mathrm{kg}$ and $20.0 \mathrm{meq} / \mathrm{kg}$ as PVs from Jatropha curcas and Hura crepitans, respectively. Manji et al. (2013), pointed out that oils with low PVs have long shelf life and are not susceptible to rancidifying agents. While higher PVs of 20 - $40 \mathrm{meq} / \mathrm{kg}$ or more, promote rancidity, precipitation of polymeric compounds formed as a result of incomplete combustion, leading to blockage of the filters of auto-engines (Montcho et al., 2018).
The crude seed oil extract of $A$. indica gave an iodine value (IV) of $66.77 \pm 2.55 \mathrm{~g} / 100 \mathrm{~g}$, lower than 105 $\mathrm{g} / 100 \mathrm{~g}$ (Jatropha curcas) and $149.64 \mathrm{~g} / 100 \mathrm{~g}$ (Hura crepitans), reported by Umaru and Aberuagba, (2012) and Ottih et al. (2015). Adewuyi et al. (2014) reported a standard (EN) value of $120 \mathrm{~g} / 100 \mathrm{~g}$. According to Jauro and Adams (2011), the iodine value (IV) of oil extracts determined their rating. Oils with IV less than $100 \mathrm{~g} / 100 \mathrm{~g}$ are classified as non-drying while those with values between $100-130 \mathrm{~g} / 100 \mathrm{~g}$ and $>130 \mathrm{~g} / 100 \mathrm{~g}$ are referred to as drying and semi-drying, respectively. In this regard, the neem seed crude oil extract is classified as non-drying (Table 2). Low IV suggests high stability against oxidation agents and suitability for biodiesel production (Nwe et al., 2019).

The saponification value (SV) of $212.96 \pm 1.16$ $\mathrm{mgKOH} / \mathrm{g}$ recorded for the crude seed oil extract of $A$. indica was found to be higher and lower than 190.00 $\mathrm{mgKOH} / \mathrm{g}$ (Jatropha curcas), 211.78-214.52 mgKOH/g (Azadirachta indica) and $220.19 \mathrm{mgKOH} / \mathrm{g}$ (Hura crepitans) as reported by Umaru and Aberuagba, (2012), Ungo-kore et al., (2019) and Ottih et al. (2015). Higher SV implies higher molecular mass and long C-C chain fatty acids (Ferhat et al., 2014). Oils with higher SV are considered appropriate for manufacturing of biodiesel, due to their lubricating enhancement tendency, which prolongs and promotes engine functional life (Ejilah et al., 2012).

The viscosity values (VV) of $2.20 \pm 0.12 \mathrm{~mm}^{2} / \mathrm{s}$ obtained from the crude seed oil of Azadirachta indica compares with the standard EN range of 3.5-5.9 mm2/s (Adewuyi et al., 2014). Higher values of $5.01 \mathrm{~mm}^{2} / \mathrm{s}$ and 40.0 $\mathrm{mm}^{2} / \mathrm{s}$ were obtained from Hura crepitans and Jatropha curcas as reported by Ottih et al. (2015) and Umaru and Aberuagba, (2012), respectively. Viscosity has been shown to affect fuel injection operation, diesel injector and, in fuel pump flow, triglycerides constituent and other chemical properties (Azuaga et al., 2018). They opined that the nature of the C-C triglyceride chains of oils varies proportionally with viscosity and inversely with density.

\section{Cetane Number and Calorific Value of Crude Seed Oil Extract of Azadirachta indica}

The crude seed oil extract of Azadirachta indica gave a cetane number $(\mathrm{CN})$ of $56.91 \pm 2.19$, higher than the 51.0 EN standard value (Adewuyi et al., 2014) and 45.62 of Hura crepitans (Ottih et al., (2015). Previous works have indicated varying $\mathrm{CN}$ values of 50.0 for Heavea brassilensis biodiesel, (Krishnakumar et al., 2013), 52.85 for Ceiba pentandra (Montcho et al., 
2018), 53.0 for neem diesel, (Banik et al., 2018), 59.0160.47 for Cyperus esculentus (Sidohounde et al., 2018). According to Aligrot (1994), the ability of any fuel to ignite is a measure of its CN. According to Montcho et al. (2018), higher cetane number reduces the ignition delay time, thereby promoting combustion efficiency. Ejilah (2012), indicated oils with more saturated $\mathrm{C}$ molecules have better combustion efficiency due to higher $\mathrm{CN}$.

The calorific value (CV) measures the unit of energy released per kilogram of fuel combusted (Montcho et al., 2018). The CV of $39.21 \pm 1.11 \mathrm{MJ} / \mathrm{Kg}$ was higher than $39.10 \mathrm{MJ} / \mathrm{Kg}$ (H. crepitans, Ottih et al., 2015) and $35.00 \mathrm{MJ} / \mathrm{Kg}$ EN standard value (Sidohounde et al., 2018), and lower than $42.0 \mathrm{MJ} / \mathrm{Kg}$ (Jatropha curcas, Umaru and Aberuagba, 2012). This suggests a good potential for biofuel production (Ofoefule et al., 2013).

\section{Flash Point (FP) of Crude Seed Oil of Azadirachta indica}

According to Jauro and Adams (2011), the flash point measures the overall flammability of an oil, such that higher values indicate a less likelihood to ignite accidentally. The FP of $80 \pm 2.1^{\circ} \mathrm{C}$ indicated from the current study was lower than $152^{\circ} \mathrm{C}$ and $108^{\circ} \mathrm{C}$ recorded for Hura crepitans and Jatropha curcas, as described by Ottih et al. (2015) and Umaru and Aberuagba, (2012), respectively. This was also below the ASTM standard of $100^{\circ} \mathrm{C}$. Raja et al. (2011) posited that fuels with flash points above $66^{\circ} \mathrm{C}$ are considered safe and suitable for all climatic conditions.

Percentage Free Fatty Acids (FFA) and Fatty Acids Composition of Crude Seed Oil Extract of Azadirachta indica

Azuaga et al. (2018), described the percentage of free fatty acid in an oil as an important variable determining the quality of oils, suggesting that oils with lower FFA indicate better quality for edibility $(\leq 10)$ and $2.0 \%$ maximum limit for high-grade (Codex Alimentairus Commission, 1993). The \%FFA of $2.13 \pm 0.05$ obtained in this study was lower than $4.61 \%$ and $18.1 \%$ obtained for Hura crepitans and Jatropha curcas as reported by Ottih et al. (2015) and Umaru and Aberuagba (2012), respectively. However, the ENEN 14214 /ASTM D6751 acid value was $0.5(\mathrm{mg} \mathrm{KOH} / \mathrm{g}) "$.

The free fatty acids composition of seed oil of Azadirachta indica revealed the presence of linoleic, hexadecanoic, octadecanoic and alpha linolenic acids, with retention time and \% composition of $18.2 \mathrm{~min}$ and $10.80 \pm 0.50 \%, 22.2 \mathrm{~min}$ and $30.01 \pm 1.79 \%, 18.2 \mathrm{~min}$ and $59.10 \pm 2.22 \%$, and 20.2 min andd $0.09 \pm 0.02 \%$ respectively. These are similar to the findings of Aransiola et al. (2012). Linolenic contents have been reported as being the least \% composition (Ejilah et al., 2012; Aransiola et al., 2012), which corroborated the present findings. The fatty acids composition of extracted crude oils are affected by some other inherent oil properties such as cetane number, viscosity, oxidation stability, and others (Sidohounde et al., 2018). The unsaturated fatty acids constituents of neem seed oil extract promote oil efficiency and shelf life.

\section{Conclusion and Recommendation}

The study has shown the presence of some important physical properties such as specific gravity, flash and melting points respectively. Chemical properties such as iodine value, refractive index, saponification value, peroxide value, acid value, viscosity value, cetane number, calorific value and free fatty acids were found to be within the standard range. Fatty acids composition of crude seed oil of Azadirachta indica included linoleic, hexadecanoic, octadecanoic and alpha linolenic acids, with retention time and \% composition of $18.2 \mathrm{~min}$ and $10.8 \pm 0.50 \%, 22.2 \mathrm{~min}$ and $30.01 \pm 1.79 \%, 18.2 \mathrm{~min}$ and $59.10 \pm 2.22 \%$, and $20.2 \mathrm{~min}$ and $0.09 \pm 0.02 \%$ respectively. These preliminary findings depict the biodiesel potential of the crude seed oil of Azadirachta indica. This, when transesterified with further treatment, could be incorporated as proximate blends in auto-engines. This therefore would necessitate intensive afforestation efforts of the plant species for sustainable utilization.

\section{Acknowledgements}

The authors are grateful to the laboratory staff of the National Research Institute for Chemical Technology (NARICT), Zaria - Kaduna State. We also express our thanks to the staff of the Herbarium Unit of the Federal College of Forestry, Jos, for their assistance and support during the field work.

\section{Reference}

Abeer, A., Idris, A. A., Nour, A. H., Ali, M.M., Erwa, I.Y., Ishag, O.A.O. and Nour, A. H. (2020). Physicochemical Properties and Fatty Acid Composition of Ocimum basilicum L. Seed Oil. Asian J. Phy. Chem. Sci. 8(1): 112. 
Abubakar, S. (2016). Preliminary study of Endomycodiversity among three ethnomedicinal plants family Meliaceae in Nigeria. J. BioSci. Biotechnol. 5(2): 195-201.

Adewoye, T.L. and Ogunleye, O. O. (2012). Optimization of Neem Seed Oil Extraction Process Using Response Surface Methodology. J. Nat. Sci. Res. 2(6): 66-76.

Adewuyi, A., Awolade, P.O. and Oderinde, R.A. (2014). Hura crepitans Seed Oil: An Alternative Feedstock for Biodiesel Production. J. Fuels. 2014: 1-8.

Al-futuh, A.I.M. (1989). Study on the processing of Balanites aegyptiaca fruits for drug, food and feed. In: Winckens GE, Hag PM (eds), New Crops for Food and Industry. London: Chapman and Hall, pp.271-279.

Aligrot, C. Champoussin, J.C., Guerrassi, N. and Claus, G.(1994). Predition of Self Ignition Delay of Different Liquid Diesel Fuels. In Proc. Int. COMODON Symposium, Sept. $3^{\text {rd }}-7^{\text {th }}$. pp331-336.

Aransiola, E. F. , Betiku, E., Ikhuomoregbe, D.I.O. and Ojumu, T.V. (2012). Production of biodiesel from crude neem oil feedstock and its emissions from internal combustion engines. Afri.J. Biotechnol. 11(22): 61786186.

ASTM (2003) ASTM D6751-08: Standard specification for biodiesel fuel (B100) blend stock for distillate fuels Annual Book of ASTM Standards (West Conshohocken, PA: ASTM International).

Atabani, A.E., Silitonga, A.S., Badruddin, I.A., Mahlia, T.M.I., Masjuki, H.H. and Mekhilef, S. (2012). A comprehensive review on biodiesel as an alternative energy resource and its characteristics. Renew.Sustain. Energy Rev. 16(4): 2070-2093.

Avhad, M. and Marchetti, J. (2015). A review on recent advancement in catalytic materials for biodiesel production. Renew. Sus. Energy Rev. 50: 696-718.

Azuaga, I. C., Igbum, G.O. and Kyenge, B. A. (2018). Extraction and Characterization of Three Tropical Seedoils: Telfairia occidentalis, Hura crepitans and Cucumeropsis mannii. Chem. Res. J. 3(6): 1-8.

Babatunde, O. A. and Bello, G. S.(2016). Comparative assessment of some Physicochemical Properties of Groundnut and Palm Oils Sold Within Kaduna Metropolis, Nigeria. IOSR J. Appl. Chem. 9(11): 22785736.
Banik, S. K., Rouf, M.A., Rabeya,T., Khanam, M., Sajal, S.I., Sabur, S.B. and Islam, M. R. (2018). Production of biodiesel from neem seed oil. Bangl. J. Sci. Ind. Res. 53(3): 211-218.

Banu, H. D, Shallangwa, T.B., Joseph, I., Magu, T.O., Hitler, L., et al. (2018). Biodiesel Production from Neem Seed (Azadirachta indica) Oil Using Calcium Oxide as Heterogeneous Catalyst. J. Phys. Chem. Biophys. 8: 266. doi:10.4172/2161-0398.1000266

Codex Alimentairus Commission(1993). Graisses et huiles vegetables, division 11 . Version Abregee FAO/WHO Codex Stan 1993, 20-1981, 23-1981.

Demirbas, M.F. (2015a). Global fossil energy policy. Ener.Edu. Sci. Technol. Part D 7: 1-14.

Demirbas, A., Balubaid, M,A., Kabli, M, et al. (2015b). Diesel fuel from waste lubricating oil by pyrolitic distillation. Petro. Sci. Technol. 33(2): 129-138.

Demirbas, A., Bafail, A., Ahmad, W. and Sheikh, M. (2016). Biodiesel production from non-edible plant oils. Ener.Explo. Exploit. 34(2): 290-318.

Ejilah, R., Lukman, A. and Bello, A. (2012). Review of Sclerocarya birrea seed oil extracted as a bioenergy resource for compression ignition engines. Int. J. Agric. Bio. Eng. 5(3): 1-9.

Ferhat, R., Laroui, S., Abdeddaim, M. (2014). Oil and fatty acids of the almonds of the crataegus azarolus. Leban. Sci. J. 15(2):73-79.

Hamadou, B., Djomdi, Falama, R.Z., Delattre, C., Pierre, G., Dubessay, P. and Michaud, P. (2020). Influence of Physicochemical Characteristics of Neem Seeds (Azadirachta indica A. Juss) on Biodiesel Production. Biomole. 10(616):1-10.

Ibeto, C.N., Okoye, C.O.B. and Ofoefule, A.U. (2012). Comparative Study of the Physicochemical Characterization of Some Oils as Potential Feedstock for Biodiesel Production. International Scholarly Research Network, ISRN. Renew. Ener.2012: 1-5.

Jauro, A. and Adams, M.H. (2011). Production and Biodegradability of Biodiesel from Balanites Aegyptiaca Seed Oil. J. Korean Chem. Soc. 55(4): 680-684.

Jibril, M., Joel, A.S., Edith, U. and Audu, A.A. (2012). Production and characterization of biodiesel from 
Jatropha oil and Neem oil. Int. J. Emer. trends Eng. Dev. 2: 313-20.

Kadam, P.V., Yadav, K.N., Shivatare, R.S., Bhilwade, S.K. and Patil, M.J. (2012). Comparative studies on fixed oil from Ocimum sanctum and Ocimum basillicum seeds. Inventi Rapid: Planta Activa, (4):1-5.

Keneni, Y. G. and Marchetti, J.M.(2017). Oil extraction from plant seeds for biodiesel production. AIMS Ener. 5(2): 316-340.

Khan, T. M.Y., Atabani, A.E., Badruddin, I.A. (2014). Recent scenario and technologies to utilize non-edible oils for biodiesel production. Renew. Sus. Ener.Rev. 37: 840-851.

Knothe, G. and Steidley, R.K.(2005) "Kinematic viscosity of biodiesel fuel components and related compounds: influence of compound structure and comparison to petrodiesel fuel components," Fuel, 84(9): 1059-1065.

Krishnakumar, U., Sivasubramanian, V. and Selvaraju, N. (2013). Physico-Chemical Properties of the Biodiesel Extracted From Rubber Seed Oil Using Solid Metal Oxide Catalysts. Int. J. Eng. Res. d Appl. 3(4): 22062209.

Krisnangkura, K. (1986). "A simple method for estimation of Cetane index of vegetable oil methyl esters," JAOCS: J. Amer. Oil Chem. Soc. 63(4): 552553.

Madai, I.J. Jande, Y. A.C. and Kivevele, T.(2020). Fast Rate Production of Biodiesel from Neem Seed Oil Using a Catalyst Made from Banana Peel Ash Loaded with Metal Oxide (Li-CaO/Fe2 (SO4)3). Advances in Materials Science and Engineering(Hindawi), 2020, 111. https://doi.Org/10.1155/2020/78 25024.

Manji, A.J., Sarah, E.E. and Modibbo, U.U. (2013). Studies on the potentials of Balanites aegyptiaca seed oil as raw material for the production of liquid cleansing agents. Int. J. Phy. Sci. 8(33): 1655-1660.

Montcho, P., Tchiakpe, L., Nonviho, G., Bothon, F.T.D. and Sidohounde, A et al. (2018). Fatty acid profile and quality parameters of Ceiba pentandra (L.) seed oil: A potential source of biodiesel. J. Petro. Technol. Alter. Fuels, 9(3): 14-19.
Nde Bup , D., Dorin, B. and Carlos, A. (2015). Optimization of microwave assisted extraction parameters of neem (Azadirachta indica A. Juss) oil using the Doehlert's experimental design. Indus. Crops Prod. 65: 233-240.

Nwe, W. H., Sotanaphun, U., Narakornwit, W., Sittisombut, C. and Wetwitayaklung, P. (2019). Physicochemical characters and fatty acid composition of Payena lucida seed oils. Thai J. Pharm. Sci. 43(2): 76-82.

Odjobo, B. O. and Umar, A. (2019). Investigation of biodiesel fuel potential of Canarium Schweinfurthii Seed and Pulp Oils. The Int. J. Eng. Sci. (IJES), 8(12): 58-61.

Ofoefule, A.U., Ibeto, C.N., Okoro, U.C. and Onukwuli, O.D.(2013). Biodiesel Production from Tigernut (Cyperus esculentus) Oil and Characterization of its Blend with Petro-diesel. Phy. Rev. Res. Int.l. 3(2): 145153.

Ogala, H., Elinge, C.M., Wawata, I..G., Adegoke, A.I., Muhammad, A.B. and Ige, A.R. (2018. Int. J. Adv. Aca. Res.| Sci.Technol. Eng. 4(4):1-12.

Ottih, O.P., Aneke, N.A.G. and Ejikeme, P.C. (2015). Production and Characterization of Paint Driers From Sand Box Seed Oil (Hura crepitans). Int. J. Inno. Sci., Eng. Technol. 2(2):71-76.

Raja, S.A., Smart, D.S.R. and Lee, C.L.R. (2011). Biodiesel production from jatropha oil and its characterization. Res. J. Chem. Sci. 1(1): 81-87.

Rizvi, S.Q.A. (2009). A comprehensive review of lubricant chemistry, technology, selection, and design. Copyright Edition, ASTM International Publication, Baltimore, USA. pp.91- 597.

Sidohounde, A., Agbangnan, D.C.P., Nonviho, G., Montcho. P.S. and Sohounhloue, C.K.D. (2018). Biodiesel potentials of two phenotypes of Cyperus esculentus unconventional oils. J. Petro. Technol. Alter. Fuels. 9(1): 1-6.

Sidohounde, A., Nonviho, G., Bothon, F.T.D., Montcho, P.S., Dossa,C.P.A., Tchiakpe, L., Sohounhloue, D.C.K. (2019). Biodiesel Synthesis by Ethanolysis of Hura crepitans Seed Oil Unfit for Consumption in Benin. Amer. J. Phy. Chem. 8(3): 50-57.

Sunmonu, M.O., Ajala, E.O., Odewole, M.M., Morrison, S. and Alabi, A. M. (2017). Comparative Analysis of 
Physico-Chemical Properties of Oil Extract From two Varieties of Fluted Pumpkin Seeds Using Different Extraction Methods. Kathmandu University J. Sci. Eng. Technol..13(1): 48-60.

Sylvester C Izah, Elijah I and Ohimain (2013), The challenge of biodiesel production from oil palm feedstock in Nigeria. Greener J. Bio. Sci. 3(1): 1-12.

Syndia, L.A.M., Prasad, P.N., Annadurai, G., Nair, R.R., Thilaga, S. and Ganesh, D. (2015). Characterization of neem seed oil and de-oiled cake for its potentiality as a biofuel and biomanure. Int. Res. J. Pharm. Biosci. 2(5): 10- 19.

Tesfaye, B., Tefera, T., Misikir, O. and Tsegaye, G. (2018). Extraction and comparison of essential oil from neem seed by using soxhlet extraction and simple distillation methods. Int. J. Eng. Technol. Manag. Res. 5(9): 74-81.

Umaru, M. and Aberuagba, F. (2012). Characteristics of a Typical Nigerian Jatropha curcas oil Seeds for Biodiesel Production. Res. J. Chem. Sci. 2(10): 7 - 12.

Ungo-kore, H.Y., Ibrahim, Y.K.E., and Tytler, B.A.(2019). Anti-dermatophytic activity and FTIR analysis of Petroleum ether extracts of Azadirachta indica A. Juss seed (Meliaceae). Novel Res. Microbio. J. 3(6): 579-589.

Wilson P (2010), Biodiesel production from Jatropha curcas: A review. Sci. Res. Essays, 5(14):1796-1808.

Zahan, K.A. and Kano, M.(2018). Biodiesel Production from Palm Oil, Its By-Products, and Mill Effluent: A Review. Energies 2018, 11，2132:1-25; doi:10.3390/en 11082132 